\title{
Students' Attitudes towards the English Proficiency Enhancement Programme
}

\author{
Engku Suhaimi Engku Atek ${ }^{1}$, Zailani Jusoh ${ }^{2}$, Alia Nabila Alias ${ }^{3}$, Wahidah \\ Abdul Wahid ${ }^{4} \&$ Izah Mohd Tahir*
}

${ }^{1}$ Faculty of Languages and Communication, Universiti Sultan Zainal Abidin

Gong Badak Campus, 21300, Kuala Terengganu, Terengganu, Malaysia

E-mail: esuhaimi@unisza.edu.my

${ }^{2}$ Faculty of Languages and Communication, Universiti Sultan Zainal Abidin

Gong Badak Campus, 21300, Kuala Terengganu, Terengganu, Malaysia

E-mail: zailani@unisza.edu.my

${ }^{3}$ Faculty of Languages and Communication, Universiti Sultan Zainal Abidin

Gong Badak Campus, 21300, Kuala Terengganu, Terengganu, Malaysia

E-mail: zalianabila@unisza.edu.my

${ }^{4}$ Faculty of Languages and Communication, Universiti Sultan Zainal Abidin

Gong Badak Campus, 21300, Kuala Terengganu, Terengganu, Malaysia

E-mail:wahidah@unisza.edu.my

Corresponding author: Izah Mohd Tahir, Faculty of Business Management and Accountancy, Universiti Sultan Zainal Abidin, Gong Badak Campus, 21300, Kuala Terengganu, Terengganu, Malaysia.E-mail: izah@unisza.edu.my

Received: March 14, 2012 Accepted: June 19, 2012 Published: July 31, 2012

doi:10.5296/ije.v4i3.1475 URL: http://dx.doi.org/10.5296/ije.v4i3.1475 


\section{Abstract}

This article examines students' attitudes towards the English Proficiency Enhancement Programme (EPEP) carried out in one of the public universities in Malaysia. It draws on a study of 167 participants of the inaugural programme in 2010. A questionnaire was administered to evaluate their attitudes towards four categories of the programme: facilitators, schedule, activities and benefits. Analysis of data was done quantitatively. A main finding is that the EPEP impacted positively on the participants. Other findings show no significant differences in attitudes between gender but attitudes between diploma and undergraduate participants were significantly different. Resultant suggestions include continuing with this programme but with some modifications.

Keywords: English proficiency enhancement programme, attitudes, public universities, Malaysia

\section{Introduction}

English is an important language in the academia. A student's mastery of the English language may not only help them excel in their studies but also secure them better jobs after graduation as employers prioritise hiring graduates who are competent in English. A Study on the Academic Achievements and Employability of Graduates in Institutions of Higher Learning (Morshidi et al. 2004) revealed that English language skills have significant effects on employability. Therefore, the mastery of English is important to a graduate to satisfy the needs of employment, especially in the private sector. In Malaysia, many students are found to have a poor command of the English language even as they embark on university education. Malay, as the national and official language of Malaysia, has been the medium of instruction in school since 1971. English though remains as the second language. Notwithstanding the 2003 Malaysian government's policy of introducing the teaching of Mathematics and Science subjects in English, its use in the educational sphere is largely restricted to being a compulsory subject at the school-level. In higher education, the democratization of universities has allowed English to play a more prominent role in teaching and learning. More undergraduate programmes are taught in English. However students that enter universities are the product of an education system that emphasizes the Malay language in its curriculum. Therefore, students are finding it difficult to grasp the English language as they attend lectures and tutorials.

Aware of the importance of English in the academia and also for better job prospects, the management of University Sultan Zainal Abidin (UniSZA) has moved in to help raise the standard of English among its students to better prepare them for university education and for employment by introducing a programme called the English Proficiency Enhancement programme (EPEP).

\subsection{The English Proficiency Enhancement Programme}

The EPEP has the twin objectives of making the students feel more confident using English and ensuring students are able to adapt themselves when working as a group in pursuit of a common goal. The participants of the programme comprised approximately 290 
fresh diploma and undergraduate students who were adjudged to have low English proficiency through a special test given. They were then placed into groups for the whole duration of the programme. Each group was assigned a specific number of facilitators to assist them.

To ensure the success of the programme, students deemed proficient in English were enrolled as facilitators, consisting mostly of senior students from the Bachelor of English and Diploma in TESL programmes. The choice of students as facilitators was based on a number of factors. Firstly, the programme would be run outside of class hours. Secondly, the programme involved a fairly large number of participants. Thirdly, student used as facilitators would help minimise the barrier between participants and facilitators, thus enhancing interaction between them. The roles of the facilitators were to supervise, guide and assist the participants in their activities.

The EPEP covered a period of two semesters in the academic session of 2009/2010. It was conducted outside class hours every Thursday afternoon for a period of two hours, adhering to the schedule and list of activities prepared beforehand. Examples of activities included Choral Speaking, TV Commercial, Lost in Jungle, Silent Movie, Shadow Play, Newspaper Collage, Speak and Sign, UniSZA Corner, Famous Lines and Speeches, and Story Telling.

The EPEP, was seen as communicative and task-based to allow students to improve their command of English beyond the formal classroom setting. In class, students rarely have opportunities to engage in meaningful use of English on a constant basis. The aim was to promote interaction between students using English as the medium. This is consistent with the view expressed by Swain (1985) and Prabhu (1987) that second language competence can be developed when learners have sufficient opportunities to participate in discourse centring on the exchange of information and the negotiation of meaning.

\subsection{Aim of Study}

There are two objectives of the study. The first objective is to determine the participants' attitudes towards the programme. Secondly, the study compares the participants' attitudes by both gender and level of studies. In particular, the study addresses the following research questions:

1) What are the participants' attitudes towards the EPEP?

2) Are there any significant differences in attitudes of the participants' by (i) gender and (ii) level of studies?

\section{Literature Review}

In second language acquisition, learners' attitudes, motivation, beliefs and perceptions of learning and teaching have been given much emphasis. (Cotterall, 1999; Gardner, 1983; Gardner and MacIntyre, 1993; Nunan, 1998; O’Nell, 1991). Attitudes and motivation have been known to play a major part in language learning. Gardner (1983) suggested that learners' attitudes to the target language, to learning the target language and to the whole 
language situation determined their level of motivation. Riley (1996), as cited in Cotterall (1999), argued that a learner's perceptions of teaching and learning may directly influence or even determine their attitude or motivation or behaviour when learning a particular language.

The construct of motivation is recognised as a multi-factorial one instead of a single entity. Oxford and Shearin (1996) identified six factors that impact motivation in language learning: attitudes (i.e. sentiments towards the learning community and the target language), beliefs about self (i.e. expectancies about one's attitudes to succeed, self-efficacy, and anxiety), goal (perceived clarity and relevance of learning goals as reasons for learning), involvement (i.e. extent to which learner actively and consciously participates in the language learning process), environmental support (i.e. extent of teacher and peer support, and the integration of cultural and outside-of-class support into learning experience) and personnel attributes (i.e. aptitude, age, sex, and previous language learning experience).

For successful transfer of language learning, factors such as positive learner and teacher attitudes, which are inter-related to motivation, must be sustained (Finocchiaro, 1982). In order to foster positive attitudes and motivate language learning, factors contributing to the conducive learning environment must be present. Krashen (1987) suggested a learning situation that has a low affective filter whereby learners learn to use a language in a non-threatening and fun environment. Other factors include providing a continuous and consistent exposure to the language being learned, providing various types of input which are auditory, visual, sensory, verbal and nonverbal in nature, an environment where the teachers and the students are supportive and encouraging and having access to situations wherein students are able to use the language as a" natural means of communication" (Littlewood, 1995:58). These factors are necessary in any language learning programme. The enhancement aspect of a language learning programme must also encompass these factors. In designing learning activities, learners must be given opportunities to participate as language users in multiple contexts. These opportunities will result in learners' heightened motivation and awareness of the intricacies of language use. Reeve (1996) expresses the belief that motivation is the trick, the secret to achieving academic excellence.

Hussein et al (2001) lists a number of activities that are able to drive students to learn the language and to sustain students' interest in learning a language. These include activities that are interrelated between in-class and out-of-class language activities, communicative (game type) integrative (short/small activities from larger activities), pleasant, safe and non-threatening, enthusiastic, group-based, meaningful or relevant, challenging. All of these activities are known to promote, self-confidence, experiences of success, learning satisfaction and good positive relationships among learners and between teachers and students.

Many educationists are of the view that participation in verbal interaction provides language learners with the opportunity to follow-up on language items they are exposed to during classroom lessons and to practise them in contexts. Learners will be able to experience greater verbal contact with each other through small group, pair work, role plays and discussions. A habitual learning style that focuses more on communicative approach to promote students to learn English should be considered (White, 1989). Studies that compared 
interaction among learners outside classroom situations with that among learners in teacher-fronted lesson found that learners working together in groups, i.e. in informal settings were found to display greater motivation, more initiative and less anxiety regarding their learning (Pica, Lincoln-Porter, Paninos and Linnell, 1996). These findings, as reported and reviewed by Long and Porter (1985), reflect on the role of interaction to facilitate and promote opportunities for second language learning

Group work is seen as one of the most effective ways of conducting language activities. In fact, a number of researchers have investigated the impacts of group work on language learners. Studies have shown that group work creates positive impacts. Group work increases language practice opportunities, improves the quality of student talk, helps individualised instruction, promotes a positive affective climate and motivates students (Long \& Porter, 1985).Littlejohn (1982) found that group work produced students who were more motivated, less inhibited, freer to speak and less conscious of mistakes. The benefits of group interaction extend to informal learning too. In a study on the impacts of group work on university students involved in outdoor activities, Ismail and Tahir (2011) found that group work enhances language proficiency of students.

Peer support is becoming a popular supplement to the traditional methods in second language learning (Deegan, 2006). Studies have shown that employing peer support system in language learning creates a more positive environment. This environment encourages students to be responsible for their own learning process, both in academic achievement and social development (Glynn, et. al, 2006). Peer support allows students to primarily interact with their peers. Interaction with peers is a good method to stimulate learning as students assisted by peers are more active and engaging (Topping, 1996). In a study on the attitudes of children to the study of French in a British school, Fitz-Gibbon and Reay (1982) found that peer tutoring increases motivation to learn a language.

\section{Research Design}

The study uses the quantitative approach. A primary survey using a detailed questionnaire was employed to measure the participants' attitudes towards the EPEP. The questionnaire was designed to gather perceptions about variables related to successful language programmes. The questionnaire comprised 31 statement items that fell under four different constructs: activities (5 items), facilitators (10 items), schedule (5 items) and benefits (11 items). Participants were asked to rate what they thought about each item. Items were rated on a 5-point Likert scale ranging from 1 (strongly disagree) to 5 (strongly agree). The instrument reliability was measured at 0.753 , indicating that the survey was reliable.

A total of 290 copies of the questionnaire were distributed to the EPEP participants. Of the 290questionnaires distributed, 167 were returned, for a response rate of approximately $57.6 \%$. Of the 167 students who answered the survey, 94 were undergraduate students and 73 diploma students. By gender, the number of male and female participants was 41 and 126 respectively. The breakdown of the respondents based on their gender and level of studies is shown in Table 1. 


\section{Macrothink}

Table 1: Demographic Profile of Respondents

\begin{tabular}{lcc}
\hline Category & $\mathrm{N}$ & Percentage \\
\hline Gender & & \\
Male & 41 & 24.6 \\
Female & 126 & 75.4 \\
Level of studies & & \\
Diploma & 73 & 43.7 \\
Undergraduate & 94 & 56.3 \\
\hline
\end{tabular}

After collection, the information from the questionnaires was entered onto an SPSS database to enable data analysis to be carried out. The data obtained from the questionnaires were analysed descriptively and inferentially.

\section{Survey Results}

The mean score indicator shown in Table 2 is used to interpret and analyse the respondent's attitudes.

Table 2: Mean Score Indicator on Attitude

\begin{tabular}{ll}
\hline Mean Score & Attitude Description \\
\hline $1.00-1.99$ & Very Negative \\
$2.00-2.99$ & Negative \\
$3.00-3.99$ & Positive \\
$4.00-5.00$ & Very Positive \\
\hline
\end{tabular}

\subsection{Attitude by Category}

Table 3 shows the mean scores based on attitudes by category. Overall, the EPEP has a positive impact on the participants $(\mathrm{M}=3.67)$. For the individual categories, participants were most positive in attitudes towards facilitators $(\mathrm{M}=3.95)$, followed by activities $(\mathrm{M}=3.90)$ and benefits $(M=3.74)$. Participants however showed a negative attitude towards schedule $(\mathrm{M}=2.64)$. This is consistent with our findings on individual statement items as shown in Table 4. Respondents were most satisfied with items relating to facilitators. This is consistent to the findings by Ismail and Tahir (2011). Respondents were least satisfied with items relating to schedule. Table 5 lists the three most and least positive statement items.

Table 3: Attitude by Category

\begin{tabular}{llll}
\hline Category & N & Mean & SD \\
\hline Overall (OVR) & 167 & 3.67 & .40 \\
Activities (ACT) & 167 & 3.90 & .54 \\
Facilitators (FACI) & 167 & 3.95 & .49 \\
Schedule (SCH) & 167 & 2.64 & .72 \\
Benefits (BEN) & 167 & 3.74 & .54 \\
\hline
\end{tabular}




\section{Macrothink}

Table 4: Attitude towards Statement Items

\begin{tabular}{|c|c|c|c|}
\hline & $\mathbf{N}$ & Mean & SD \\
\hline \multicolumn{4}{|l|}{ Activities } \\
\hline 1. Activities are fun and enjoyable. & 167 & 3.99 & .716 \\
\hline 2. Activities are appropriate to my level. & 167 & 3.91 & .693 \\
\hline 3. Activities are beneficial. & 167 & 3.74 & .814 \\
\hline 4. Activities allow me to interact with others using English. & 167 & 3.88 & .743 \\
\hline $\begin{array}{l}\text { 5. Activities give me the opportunity to polish up my spoken } \\
\text { English. }\end{array}$ & 167 & 3.99 & .699 \\
\hline \multicolumn{4}{|l|}{ Facilitators } \\
\hline 6. Facilitators are committed. & 167 & 4.01 & .658 \\
\hline 7. Facilitators are helpful and supportive. & 167 & 4.04 & .680 \\
\hline 8. Facilitators make me feel welcome. & 167 & 4.07 & .641 \\
\hline 9. Facilitators give clear instructions. & 167 & 4.01 & .606 \\
\hline 10. Facilitators guide me throughout the programme. & 167 & 3.94 & .692 \\
\hline 11. Facilitators have good command of English. & 167 & 4.03 & .595 \\
\hline 12. Facilitators handle the activities well. & 167 & 3.98 & 611 \\
\hline 13. Facilitators help with my preparation. & 167 & 3.95 & 679 \\
\hline 14. Facilitators are well-trained. & 167 & 3.86 & .643 \\
\hline 15. Facilitators are always on time. & 167 & 3.84 & .824 \\
\hline \multicolumn{4}{|l|}{ Schedule* $^{*}$} \\
\hline 16. Two semesters is too long. & 167 & 2.67 & 1.148 \\
\hline 17. Two hours a week is insufficient. & 167 & 2.57 & .940 \\
\hline 18. Having activities on Thursday afternoon isn't suitable. & 167 & 2.63 & 1.089 \\
\hline 19. Timetable isn't flexible. & 167 & 2.29 & .845 \\
\hline 20. Activities are always rescheduled or cancelled. & 167 & 3.05 & .965 \\
\hline \multicolumn{4}{|l|}{ Benefits } \\
\hline 21. I use English all the time. & 167 & 3.26 & .859 \\
\hline 22. The programme has improved my English. & 167 & 3.89 & .779 \\
\hline 23. I am now more confident in using English. & 167 & 3.78 & .771 \\
\hline 24. I am very committed to the programme. & 167 & 3.80 & .713 \\
\hline 25. I am extremely motivated to learn English. & 167 & 3.72 & .812 \\
\hline 26. I want to continue participating in this programme. & 167 & 3.87 & .704 \\
\hline 27. EPEP is a very interesting programme. & 167 & 3.54 & .856 \\
\hline 28. The time spent in this programme is worthwhile. & 167 & 3.90 & .848 \\
\hline 29. This programme allows me to speak English in public. & 167 & 3.78 & .830 \\
\hline 30. I have been given ample opportunity to practice English. & 167 & 3.69 & .864 \\
\hline 31. I find support from lecturers encouraging. & 167 & 3.87 & 687 \\
\hline
\end{tabular}

Note: *Items were reverse-coded 
Table 5: Most Positive and Least Positive Statement Items

\begin{tabular}{l|l}
\hline $\begin{array}{c}\text { Most Positive Statement Items (Top } \\
\text { three ) }\end{array}$ & Least Positive Statement Items (Bottom three) \\
\hline $\begin{array}{l}\text { 1. Facilitators make me feel welcome } \\
\text { 2. Facilitators are very helpful }\end{array}$ & $\begin{array}{l}\text { 29. Having activities on Thursday afternoon isn't } \\
\text { suitable } \\
\text { 30.Two hours a week is insufficient } \\
\text { English }\end{array}$ \\
\hline
\end{tabular}

\subsection{Attitude by Gender}

To measure the impact of gender on the attitudes towards the EPEP, an independent-samples t-test was conducted. Results are shown in Table 6. No significant differences between male and female participants were found both in their overall attitudes towards the programme and each of the four categories. While the study shows that gender does not have any impact on their perceptions of the EPEP, female participants showed a more positive attitude towards both facilitators and benefits as their slightly higher mean scores indicated. For attitudes towards schedule, though both male and female respondents generally displayed negative attitude, male respondents were found to be less negative.

Table 6: Attitude by Gender

\begin{tabular}{lllllll}
\hline Category & Gender & $\mathbf{N}$ & Mean & SD & $\boldsymbol{t}$ & Sig. (2-tailed) \\
\hline Activities & Male & 41 & 3.90 & .59 & -.024 & .981 \\
& Female & 126 & 3.90 & .52 & & \\
Facilitators & Male & 41 & 3.93 & .52 & -.217 & .829 \\
& Female & 126 & 3.95 & .47 & & \\
Schedule & Male & 41 & 2.8 & .73 & 1.664 & .098 \\
& Female & 126 & 2.6 & .71 & & \\
Benefits & Male & 41 & 3.70 & .64 & -.472 & .638 \\
& Female & 126 & 3.75 & .51 & & \\
& Male & 41 & 3.67 & .50 & -.145 & .885 \\
& Female & 126 & 3.66 & .37 & & \\
\hline
\end{tabular}

\subsection{Attitude by Level of Studies}

Another independent-samples t-test was conducted to compare the attitudes of diploma and undergraduate participants towards the EPEP. Their findings are shown in Table 7. There were significant differences in the overall scores for diploma students $(\mathrm{M}=3.74$, $\mathrm{SD}=0.453)$ and undergraduate students $(\mathrm{M}=3.61, \mathrm{SD}=0.35) ; \mathrm{t}(165)=2.09, \mathrm{p}=0.038$. These results indicate that significant differences existed between undergraduate and diploma participants in their overall attitudes towards the EPEP. When comparing their attitudes towards the individual categories, significant differences towards schedule were also found. Diploma participants showed a more positive attitude $(\mathrm{M}=2.94, \mathrm{SD}=.70)$ than undergraduate students $(\mathrm{M}=2.42, \mathrm{SD}=.65) ; \mathrm{t}(165)=4.98, \mathrm{p}=0.000$. Another significant finding is that 
Diploma participants obtained higher mean scores for all categories of the EPEP, indicating their better overall perception of the programme.

Table 7: Attitude by Level of Studies

\begin{tabular}{llllllc}
\hline Category & $\begin{array}{c}\text { Level of } \\
\text { studies }\end{array}$ & $\mathbf{N}$ & Mean & SD & $\boldsymbol{t}$ & Sig. (2-tailed) \\
\hline Overall & Diploma & 73 & 3.74 & .45 & 2.09 & $.038^{*}$ \\
& Undergraduate & 94 & 3.61 & .35 & & \\
\hline Activities & Diploma & 73 & 3.98 & .54 & 1.51 & .133 \\
& Undergraduate & 94 & 3.85 & .54 & & .528 \\
\hline Facilitators & Diploma & 73 & 3.97 & .49 & .63 & $.000^{*}$ \\
& Undergraduate & 94 & 3.92 & .48 & & .673 \\
\hline Schedule & Diploma & 73 & 2.94 & .70 & 4.98 & \\
& Undergraduate & 94 & 2.42 & .65 & & .422 \\
\hline Benefits & Diploma & 73 & 3.76 & .62 & & \\
& Undergraduate & 94 & 3.72 & .48 & &
\end{tabular}

\section{Conclusions}

A number of conclusions can be drawn from this study. Firstly, the EPEP has impacted positively on the participants. Their overall perception of the EPEP is positive. The participants also perceived positively the categories of facilitators, activities and benefits. Only in the category of schedule were the participants' attitudes negative. Secondly, there was no significant impact of gender on the participants' attitudes towards the EPEP. Thirdly, the participants' level of studies did contribute towards the significant differences in their overall perception of the EPEP. Diploma rather than undergraduate participants were found to have formed a more positive attitude towards the EPEP.

Resultant recommendations include continuing with the EPEP with several modifications. Subsequent EPEP programme will benefit from the outcome of this study. The schedule should be more accommodating to the students in order to optimise their involvement and participation. Our research show the participants' felt that the slot on Thursday afternoon was rigid and inflexible, thus undermining their planned activities or obligations. A sizeable number of the participants were forced to choose between participating in the programme and attending other activities such replacement classes, tests and co-curricular activities. In spite of the modifications suggested, the practice of using students as facilitators and group work activities should be allowed to flourish. These arrangements have proved to have greatly benefitted the EPEP participants. 


\section{References}

Cotteral, S. (1999). Key variables in language learning: what do learners believe about them? System, 27, 493-513. Retrieved from http://elsevier.com/locate/system

Deegan, P. (2006). The Legacy of Peer Support. Retrieved July 30, 2011, from http://www.patdegan.com/blog/posts/legacy-peer-support

Finocchiaro, M. (1982). Motivation: it's crucial role in language learning. ERIC Document Reproduction Service.

Fitz-Gibbon, C.I., \& Rear, D.G. (1982). Peer Tutoring: Brightening up FL Teaching in an Urban Comprehensive School. British Journal of Language Teaching, 20(1), 39-44.

Gardner, R. C., \& MacIntyre, P.D. (1993).A student's contributions to second language learning. Part II: Affective Variables. Language Teaching, 26, 1-11.

Gardner, R. C. (1983). Learning another language: A true Social Psychological Experiment. Journal of Language and Social Psychology, 2, 219-239. http://dx.doi.org/10.1177/0261927X8300200209

Glynn, L., Macfarlane, A. Kelly, M., Cantillon, P., \& Murphy, A. (2006). Helping each Other to Learn - A Process Evaluation of Peer Assisted Learning. BMC Medical education, 6(1), 18-26.

Hussein, S., Maarof, N., \& D'Cruz, J. (2001). Sustaining an Interest in Learning English and Increasing the Motivation to Learn English: An Enrichment Program. The Internet TESL Journal, VII(5), May. Retrieved from http://iteslj.org/

Ismail, N.S., \& Tahir, I. M. (2011). English Camp Activities: A Strategy to Enhance Students' English Proficiency. Studies in Literature and Language, 2(3), 61-72. http://dx.doi.org/10.3968/j.sll.1923156320110203.009

Krashen, S. D. (1987). Principles and practice in second language acquisition. New York: Prentice Hall.

Littlejohn, A.P. (1982). Teacherless language Learning Groups: An Experiment. Manuscript, University of Lancaster.

Littlewood, W. (1995). Foreign and second language learning. Cambridge: CUP.

Long, M., \& Porter, P.A. (1985). Group Work, Interlanguage Talk, and Second language Acquisition. TESOL Quarterly, 19(2), 207-228, June.

Morshidi Sirat, Rosni Bakar, Lim Hock Eam dan Mohamed Nasser Katib. (2004). Kajian Pencapaian Akademik dan Kebolehgunaan Tenaga Siswazah di Institusi PengajianTinggi. UniversitiSains Malaysia: Institusi Penyelidikan Pendidikan Tinggi Negara.

Nunan, D. (1988). The learner Centred curriculum: A study in Second language Teaching. Cambridge: Cambridge University Press. 


\section{Macrothink}

O'Neill, R. (1991). The plausible myth of learner centredness: Or the importance of doing ordinary things well. ELT Journal, 45, 293-304.

Oxford \& Shearin, 1996. Language Learning Motivation in a new key. In Rebecca Oxford Ed., Language Learning Motivation: Pathways to the New Century, University of Hawai'i Press.

Pica, T., Lincoln-Porter, F., Paninos, D., \& Linnell, J. (1996). Language Learners' interaction: How does it address the input, output, and feedback needs of L2 learners? TESOL Quarterly, 30(1), 59-84.

Prabhu, N.S. (1987). Second Language Pedagogy. Oxford: Oxford University Press.

Reeve, J. (1996). Motivating others: Nurturing inner motivational resources. Massachusetts: Allyn \& Bacon.

Swain, M. (1985). Communicative Competence: Some roles of comprehensible input and comprehensible output in its development. In S. Gass and C. Madden (Eds.), Input in second language acquisition (pp. 235-253). Rowley, MA: Newbury House

Topping, K. J. (1996). The Effectiveness of Peer Tutoring in Further and Higher Education: A Typology and Review of the Literature. Higher Education, 32(3), 321 -345.

\section{Copyright Disclaimer}

Copyright reserved by the author(s).

This article is an open-access article distributed under the terms and conditions of the Creative Commons Attribution license (http://creativecommons.org/licenses/by/3.0/). 